\title{
Some ants recently intercepted entering New Zealand (Hymenoptera : Formicidae)
}

\author{
J. B. KEALL* \\ Plant Health Diagnostic Station, MAF, Private Bag, Levin
}

\begin{abstract}
Six species of ants have been intercepted entering New Zealand recently by Port Agriculture Officers, MAF: Cardiocondyla nuda, Strumigenys godeffroyi, Pheidole umbonata, Solenopsis papuana, Pristomyrmex pungens, and Iridomyrmex purpureus. None is known to be established.

Keywords: Hymenoptera, Formicidae, interceptions, New Zealand

The quarantine records of the Ministry of Agriculture and Fisheries show that over the last 20 years ants (Formicidae) have been the second most commonly intercepted family of insects after armoured scales (Homoptera : Diaspididae). This interception rate is significant as New Zealand's ant fauna is small, with only 34 known established species, about one quarter of which have been introduced within this last 20 year period.

The species described below are of interest as, with one exception, these are the only occasions on which they have been intercepted entering this country. None is known to be established here. All the interceptions were made at Auckland by Port Agriculture Officers. Voucher specimens of these species are in the Plant Health Diagnostic Station collection at Levin.
\end{abstract}

* Author's present address: Port Agriculture Service, MAF, Box 1254, Auckland. 


\section{Subfamily MYRMICINAE}

\section{Cardiocondyla nuda Mayr (Fig. 1)}

On 4 March 19771 live worker was found on orchids from the Cook Islands by N. A. P. Lomax.

The adult worker is about $1.5 \mathrm{~mm}$ long with the head and thorax dark brown and densely punctate, and a black gaster. From above the postpetiole is nearly twice as broad as the petiole. This is a tramp species, probably of African origin, that has been spread by commerce throughout the warmer parts of the world (Wilson and Taylor 1967).

\section{Strumigenys godeffroyi Mayr (Fig. 2)}

This species has been intercepted twice. On 10 March 1978 a sample of taro tubers (Colocasia esculenta) from Western Samoa was sent to Levin by J. E. Hager. On examination 2 dead workers were found. On 2 December 1978 a live de-alate queen was found on a taro tuber from Samoa by B. R. Barnett.

This unusual genus is characterised by long narrow mandibles and the petiole being surrounded with whitish spongiform material. The workers are about $2 \mathrm{~mm}$ long and the queens are slightly larger. They are predators of small arthropods, especially certain families of Collembola (Brown 1958). S. godeffroyi is regarded as a tramp species, native to tropical southeastern Asia, which has spread widely from Madagascar to Polynesia, including the Hawaiian Islands (Taylor 1976). The interception of a queen on commercial produce is a good example of what is probably a major mode of dispersal for the species.

\section{Pheidole umbonata Mayr (Fig. 3)}

This species was intercepted 3 times from Tonga in the space of one year. On 22 July 19773 live ants, 1 soldier and 2 minor workers were found on taro tubers (C. esculenta) by L. T. Pattison. On 13 April 19781 damaged minor worker was found on some unidentified leaves by D. V. Farr. On 29 April 19781 dead minor worker was found on taro leaves ( $C$. esculenta) by B. J. Southon.

Brown (1958) records this species as having been intercepted prior to 1958 , but to the author's knowledge these are the only ones intercepted since and are the only specimens in the Levin collection.

This is a small species of Pheidole, the soldiers and minor workers being about $2 \mathrm{~mm}$ and $1.5 \mathrm{~mm}$ long respectively. Colouration ranges from reddish yellow to dark reddish brown. Soldiers are easily distinguished in having the head enlarged and out of proportion to the rest of the body. It is a tropical species occurring in rain forests and plantations, and is widespread in the Pacific from the Oriental region and New Guinea to the Marquesas Islands (Wilson and Taylor 1967).

\section{Solenopsis papuana Emery (Fig. 4)}

This species was intercepted twice in one month. On 10 August 197712 live workers and some eggs were found in a taro tuber ( $C$. esculenta) from the Cook Islands by $\mathbf{M}$. Montefiane, and on 30 August 197716 live workers were found in a taro tuber $(C$. esculenta) from Fiji by P. C. Smith. No queen was found in either case.

The adult worker is about $1.5 \mathrm{~mm}$ long and light brownish yellow. It is an inconspicuous species occurring in the tropical rainforests of New Guinea, Samoa, Tonga, Fiji, Cook and Solomon Islands, and other Pacific Islands (Wilson and Taylor 1967). 

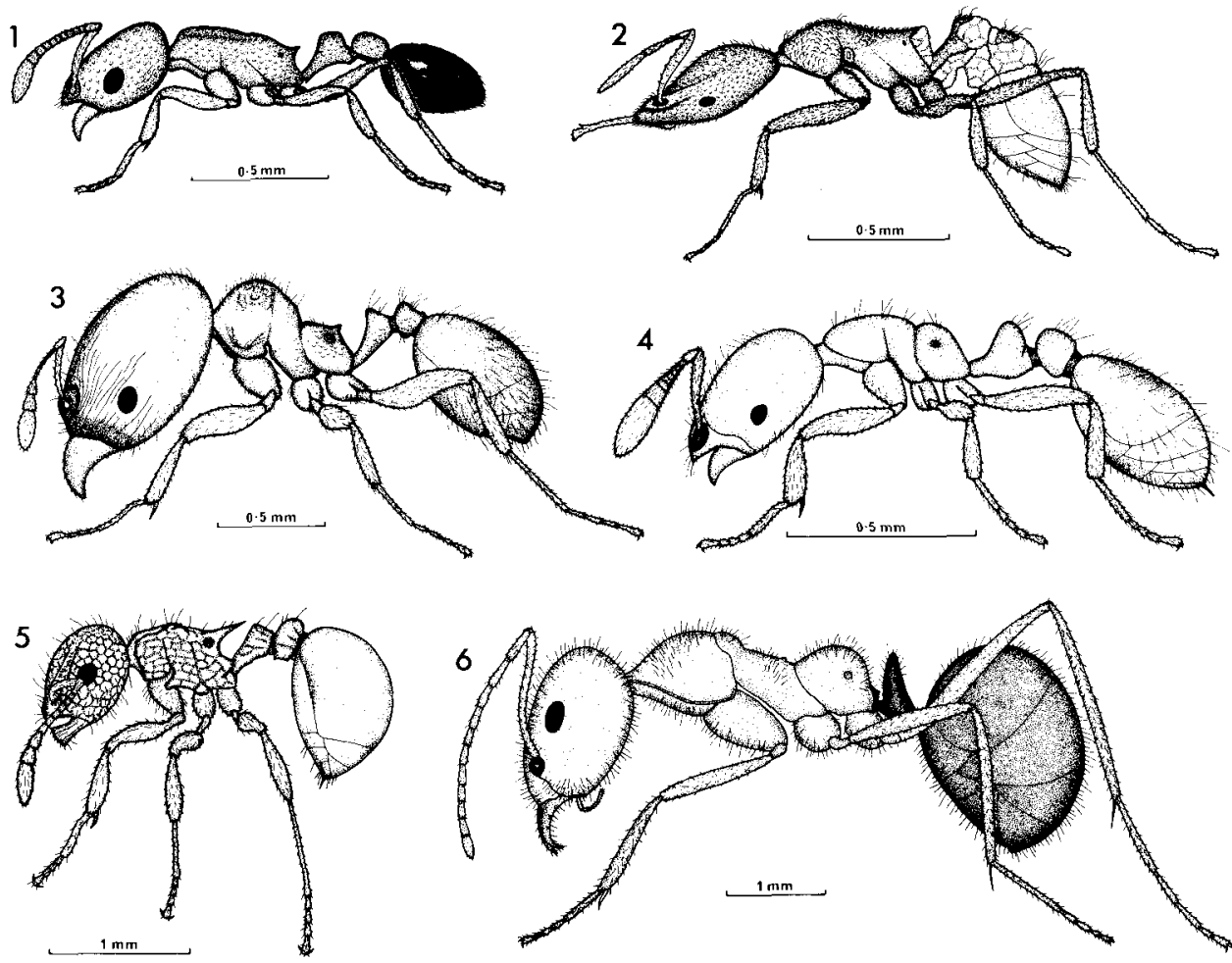

\section{Pristomyrmex pungens Mayr (Fig. 5)}

This species has been intercepted 3 times from Singapore. The first occasion was on 11 February 1972 when 1 dead worker was found on orchids by M. A. Knight. Then on 17 April 19771 live worker was found in a carton of unidentified plant material by N. C. Scott, and was subsequently identified by the Commonwealth Institute of Entomology. (The previous specimen was not identified until this time.) On 18 December 1977 another dead worker was found on orchids by B. J. Southon.

The adult worker is about $2.5 \mathrm{~mm}$ long, dark reddish brown with a heavily sculptured head and thorax, and large propodeal spines. The biology and distribution of this particular species is not known. However the genus Pristomyrmex contains over 40 named forms which occur mostly in the rainforests of the Ethiopian, Oriental, and Australian regions, where they usually nest in rotting logs (Taylor 1965).

\section{Subfamily DOLICHODERINAE}

\section{Iridomyrmex purpureus Smith (Fig. 6)}

This species has been intercepted twice in baggage from Australia. On 17 January 19762 dead workers were found by N. A. P. Lomax, and on 3 February 19781 dead worker was found by P. J. Doherty.

This is a large ant, the workers being about $7 \mathrm{~mm}$ long with a reddish head and thorax, and an iridescent bluish gaster. It is known as the meat ant and is common throughout Australia where it is regarded as a pest in some areas. Greaves (1973) states, "When the new National Capital, Canberra, was established in a partly cleared savannah woodland area, unpaved streets, gravel paths and driveways provided many additional sites for meat ant nest mounds, while parks, plantations and home gardens 
increased the amount of food and trees in foraging areas. As a result, the meat ant flourished there and the problem of controlling the species has been studied continuously from 1929 onwards'”.

\section{AGKNOWLEDGMENTS}

Dr R. W. Taylor, Division of Entomology, CSIRO, Canberra, for confirming the identity of all the species listed, except the Pristomyrmex which was identified by Dr B. Bolton of CIE, London.

\section{REFERENGES}

Brown, W. L. JR. 1958: A review of the ants of New Zealand. Acta Hymenopterologica 1(1):1-50.

GREAVES, T. 1973: Biological problems in the control of the meat ant, Iridomyrmex purpureus (Hymenoptera: Formicidae). Journal of the Australian Entomological Society 12:284-8.

TAYlor, R. W. 1965: The Australian ants of the genus Pristomyrmex, with a case of apparent character displacement. Psyche 72(1):35-54.

1976: The ants of Rennell and Bellona Islands. The Natural History of Rennell Island, British Solomon Islands 7:73-90.

Wilson, E. O.; TAYlor, R. W. 1967: The ants of Polynesia. Pacific Insects Monograph 14:1-109. 